\title{
Survey of Antimicrobial Susceptibility Patterns of the Bacteria of the Bacteroides fragilis Group Isolated from the Intestinal Tract of Children
}

\author{
Viviane Nakano $^{++}$, Mario Julio Avila-Campos ${ }^{+}$
}

Laboratório de Anaeróbios, Departamento de Microbiologia, Instituto de Ciências Biomédicas II, Universidade de São Paulo, Avenida Professor Lineu Prestes 1374 - $2^{\circ}$ andar, 05508-900 São Paulo, SP, Brasil

The bacteria of the Bacteroides fragilis group are considered important clinical pathogens and they are the most common anaerobes isolated from human endogenous infections. In this study, the susceptibility patterns to antibiotics and metals of 114 species of the $\mathrm{B}$. fragilis group isolated from children with and without diarrhea were determined. Susceptibility was assayed by using an agar dilution method with Wilkins-Chalgren agar. All B. fragilis strains were resistant to lead and nickel, but susceptible to metronidazole and imipenem. $\beta$-lactamase production was detected by using biological and nitrocefin methods, respectively, in 50\% and $90.6 \%$ of the isolates of children with diarrhea and in 60\% and 90\% of the isolates of children without diarrhea. Our results show an increase of antibiotics and metals resistance in this microbial group, and a periodic evaluation of the antimicrobial susceptibility is needed. In Brazil, the contamination for antibiotics or metal ions is often observed, and it is suggested an increase the antimicrobial resistance surveillance of this microbial group, mainly those isolated from children's diarrhea.

Key words: Bacteroides fragilis species - antimicrobial susceptibility - $\beta$-lactamase enzyme

Bacteroides fragilis is considered an important clinical pathogen and it is the most common anaerobe isolated from human clinical specimens producing endogenous infections (Duerden 1994). Species of the B. fragilis group have shown an increase of the resistance to most of the antimicrobial agents traditionally used for treating anaerobic infections. Antibiotics and metal ions have been used in the treatment of these infections but it has been a complicated process because of the bacterial resistance to these drugs, particularly in B. fragilis species (Salyers 1984).

It is well known that antimicrobial drugs can produce alterations on host's indigenous microbiota selecting resistant organisms, which can appear as opportunistic pathogens (Bezirtzoglou 1997). B. fragilis group bacteria have been studied because of their pathogenic potential and because of their unusual multiple resistances to several antibiotics (Bartlett et al. 1983) and heavy metals (Salyers 1984, Avila-Campos et al. 1991), which can be either transferred to intra- and inter-species or to other intestinal bacteria, including gram-negative facultative anaerobic ones, e.g. Escherichia coli (Tally et al. 1979).

In facultative organisms, the heavy metal resistance is plasmid-mediated and it has been extensively studied. In these organisms, the resistance markers to metals such

Financial support: Fundação de Amparo à Pesquisa do Estado de São Paulo, grant 99/06475-1

${ }^{+}$Corresponding author: Fax: +55-11-3091.7344/3091.7354. Email:mariojac@usp.br

${ }^{++}$Fapesp fellowship (00/09741-3)

Received 23 October 2003

Accepted 29 April 2004 as mercury and arsenic are usual on plasmids carrying multiple antibiotic resistance genes (Nakahara et al. 1977). Moreover, these genetic markers have been observed among species of the human indigenous amphibiotic microbiota as well as in clinical isolates (Welch et al. 1979).

Several studies have demonstrated that transferable plasmids in Bacteroides spp. play an important role in the dissemination of resistance to antibiotics, but their resistance to heavy metals is rarely reported in the literature (Riley \& Mee 1982, Rudrik et al. 1985).

The emergence and the increase of resistance to some antimicrobial agents, including tetracycline, clindamycin, cefoxitin, and metallic ions, reflect the capacity of the $B$. fragilis group in developing resistance via different mechanisms.

In developing countries, self-prescription and the use of over-the-counter antimicrobials is very common (Kunin 1993), which may lead to the emergence of a bacterial resistance in the indigenous intestinal anaerobic microbiota (Wexler et al. 2001). Thus, it is necessary to carry out a continuing assessment to the activity of antimicrobial agents against these bacteria and search for new efficacious antibiotics.

The National Committee for Clinical Laboratory Standards (NCCLS) has recommended to be performed a periodic evaluation of the susceptibility patterns of anaerobes producing infections, particularly species of the $B$. fragilis group, in order to provide more information to physicians about the treatment of infectious processes.

In this study, the antimicrobial susceptibility patterns of the bacteria of the $B$. fragilis group isolated from children's intestinal microbiota was determined.

\section{MATERIALS AND METHODS}

Bacteria - Bacteria were obtained from diarrhea stool samples collected from two child hospitals in São Paulo 
(Hospital Menino Jesus and Instituto da Criança do Hospital das Clínicas) and from healthy children from two state day care centers (Maria do Belém and Vila Carmosina, SP), from April to December 2000. None of the children received antibiotic therapy before the sample collection. A total of 114 species of the B. fragilis group was tested: 64 strains isolated from 15 children with diarrhea, and 50 strains from 24 children without diarrhea, both groups ranged from 2 months to 6 years old. Bacteria were plated onto $B$. fragilis-bile-esculin agar and identified by established methodology (Holdeman et al. 1977). All the isolates were stored in $10 \%$ skim-milk at $-80^{\circ} \mathrm{C}$ at the Anaerobe Laboratory, Department of Microbiology until the susceptibility tests could be done. The Ethic Commission of the hospitals and of the Institute of Biomedical Sciences of the University of São Paulo approved this study.

Antibiotics and metal ions susceptibility testing - The antibiotics used were the following: amoxicillin, ampicillin, clindamycin, erythromycin, and tetracycline (Luper Ind. Farm. Ltd., São Paulo, SP, Brazil); amoxicillin/clavulanic acid (Smithkline Beecham Brazil Ltd., SP); cefoxitin and imipenem (Merck, Sharp \& Dohme, SP); penicillin G (Prodoti Lab. Farm. Ltd., SP), and metronidazole (Aventis Farm. Ltd., SP). The metals used were the following: mercuric chloride $\left(\mathrm{HgCl}_{2}\right)$, silver nitrate $\left(\mathrm{AgNO}_{3}\right)$, copper sulfate $\left(\mathrm{CuSO}_{4}\right)$ and nickel sulfate $\left(\mathrm{NiSO}_{4} 6 \mathrm{H}_{2} \mathrm{O}\right)$ (Labsynth Prod. Lab. Ltd., SP); cadmium sulfate $\left(3 \mathrm{CdSO}_{4} \cdot 8 \mathrm{H}_{2} \mathrm{O}\right)$ and lead chloride $\left(\mathrm{PbCl}_{2}\right)$ (Vetec Química Fina Ltd., SP).

Antimicrobial susceptibility tests were performed by using an agar dilution method according to NCCLS (1997) using the Wilkins-Chalgren agar. Plates containing twofold serial dilutions of antimicrobial agents ranging from 0.25 to $512 \mu \mathrm{g} / \mathrm{ml}$ were used, and the final inoculum delivered by a Steers replicator was $1.5 \times 10^{5} \mathrm{cfu} /$ spot. Plates without antibiotics or metals were used as controls. All the plates were incubated in anaerobiosis $\left(90 \% \mathrm{~N}_{2} / 10 \%\right.$ $\mathrm{CO}_{2}$ ), at $37^{\circ} \mathrm{C}$, for $48 \mathrm{~h}$. The minimal inhibitory concentration (MIC) was defined as being the lowest concentration of each antimicrobial agent able to inhibit the macroscopic bacterial growth or any distinct change from the growth control. Reference strains B. fragilis ATCC 43858 and GAI 97124 were included in each experiment to assess the reliability of the method. Moreover, all the tests were done in duplicate.

Determination of $\beta$-lactamase activity - Penicillin-resistant strains were tested to verify the $\beta$-lactamase production by using biological (Paula et al. 2003) and nitrocefin methods. The biological method was as it follows: $20 \mu \mathrm{l}$ of a bacterial growth was inoculated, in duplicate, onto BHI agar containing $32 \mu \mathrm{g} / \mathrm{ml}$ of penicillin. After incubation (anaerobiosis, $37^{\circ} \mathrm{C}, 48 \mathrm{~h}$ ), the growth was exposed to chloroform vapors during $20 \mathrm{~min}$. Then, $3 \mathrm{ml}$ of BHI $(0.7 \%$ agar) inoculated with Actinomyces viscosus ATCC 910144 susceptible to penicillin $(\leq 0.25 \mu \mathrm{g} / \mathrm{ml})$ was pour-plated. Plates were incubated in anaerobic conditions, at $37^{\circ} \mathrm{C}$, for $72 \mathrm{~h}$, and the presence of a growth halo over killed bacteria was considered as producing $\beta$ lactamase. The hydrolysis of the chromogenic cephalosporin, nitrocefin (Oxoid Ltd., SP) was used as well. Briefly, a drop of nitrocefin was deposited on a microscope slide and a colony was dissolved on it. Then, the mixture was incubated at room temperature for $30 \mathrm{~min}$. The $\beta$-lactamase activity was expressed as it follows: negative, no color alterations, and positive, red colored. In both methods a penicillin-resistant and a $\beta$-lactamasepositive $B$. fragilis ATCC 43858 and GAI 97124 were used.

\section{RESULTS}

Analyzed isolates - From the 114 analyzed species of the $B$. fragilis group (64 strains from diarrhea and 50 from normal stools), $B$. fragilis ranked first, being recovered in $60 \%$ and in 54\%, respectively. Among species isolated from children with diarrhea $B$. vulgatus was recovered in $12.5 \%$, followed by B. uniformis and B. distasonis (9.3\%) and $B$. ovatus $(3.1 \%)$. Among species isolated from children without diarrhea B. distasonis was recovered in $20 \%$, B. vulgatus (12\%), B. eggerthii, B. ovatus, and B. thetaiotaomicron (4\%), and B. uniformis (2\%).

Antimicrobial susceptibilities - MIC values as well as the resistance rates to antibiotics and metal ions of species of the B. fragilis group isolated from children with and without diarrhea are expressed in Tables I and II, respectively. Isolates were uniformly susceptible to imipenem and metronidazole. Species isolated from children with and without diarrhea showed the following resistance rates, respectively: amoxicillin, $90.5 \%$ and $96 \%$; ampicillin, $92 \%$ and $98 \%$; cefoxitin, $23.5 \%$ and $22 \%$; clindamycin, $34.5 \%$ and $30 \%$; erythromycin, $97 \%$ and $100 \%$; penicillin G, $87.5 \%$ and $92 \%$; and tetracycline, $51.5 \%$ and $54 \%$. The association amoxicillin/clavulanic acid showed a middle activity with resistance rates of $40.5 \%$ and $56 \%$, respectively, in species of the B. fragilis group isolated from children with and without diarrhea.

In all tested metal ions, the resistance rates for isolates of the B. fragilis group in both groups ranged from $59 \%$ to $100 \%$ (Table II). Mercuric chloride showed a better activity than other ions, showing $\mathrm{MIC}_{90}<8 \mu \mathrm{g} / \mathrm{ml}$ and $\mathrm{MIC}_{90}<4 \mu \mathrm{g} / \mathrm{ml}$, respectively, for isolates from children with and without diarrhea. The isolates from both children groups showed, respectively, resistance rates of $59 \%$ and $80 \%$ to mercuric chloride $\left(\mathrm{HgCl}_{2}\right) ; 70 \%$ and $94 \%$ to silver nitrate $\left(\mathrm{AgNO}_{3}\right) ; 68.5 \%$ and $86 \%$ to copper sulfate $\left(\mathrm{CuSO}_{4}\right) ; 68.5 \%$ and $100 \%$ to cadmium sulfate $\left(3 \mathrm{CdSO}_{4} \cdot 8 \mathrm{H}_{2} \mathrm{O}\right)$. A high resistance rate of $100 \%$ was observed to lead chloride $\left(\mathrm{PbCl}_{2}\right)$ and to nickel sulfate $\left(\mathrm{NiSO}_{4} \cdot 6 \mathrm{H}_{2} \mathrm{O}\right)$.

Detection of $\beta$-lactamase - Most of $\beta$-lactamase producing isolates from both children's groups could be detected by using both biological and nitrocefin methods (Table III). The $\beta$-lactamase activity through biological methods was confirmed in 32 (50\%) of the 64 tested isolates tested from children with diarrhea and in $30(60 \%)$ of the 50 isolates from healthy children. Moreover, this enzyme was detected for nitrocefin in $58(90.6 \%)$ of the 64 isolates from children with diarrhea and in $45(90 \%)$ of the 50 isolates from healthy children. It was observed differences in the detection of the $\beta$-lactamase production when both methods were used. Nitrocefin method was more sensible to detect the $\beta$-lactamase activity. However, all the $\beta$-lactamase-positive strains of the $B$. fragilis group were considered high producers in spite of their phenotype resistance. 
TABLE I

Activity of antibiotics against species of the Bacteroides fragilis group isolated from intestinal microbiota of children with (64) and without (50) diarrhea

\begin{tabular}{|c|c|c|c|c|c|}
\hline \multirow[b]{2}{*}{ Antibiotics ${ }^{a}$} & \multirow{2}{*}{$\begin{array}{c}\text { Breakpoint } \\
\mu \mathrm{g} / \mathrm{ml}\end{array}$} & \multicolumn{3}{|c|}{$\operatorname{MIC}(\mu \mathrm{g} / \mathrm{ml})$} & \multirow{2}{*}{$\begin{array}{c}(\%) \\
\text { Resistance }\end{array}$} \\
\hline & & Range & $50 \%$ & $90 \%$ & \\
\hline \multicolumn{6}{|l|}{ Children with diarrhea } \\
\hline Amoxicillin & 8 & $4-256$ & 32 & 256 & 90.5 \\
\hline Amoxcillin/Clavulanic acid & 8 & $\leq 0.25-64$ & 8 & 32 & 40.5 \\
\hline Ampicillin & 4 & $\leq 0.25-256$ & 16 & 256 & 92 \\
\hline Cefoxitin & 16 & $\leq 0.25-256$ & 16 & 32 & 23.5 \\
\hline Clindamycin & 8 & $\leq 0.25-256$ & $\leq 0.25$ & 256 & 34.5 \\
\hline Chloramphenicol & 16 & $64-128$ & 128 & 256 & 100 \\
\hline Erythromycin & 8 & $\leq 0.25-256$ & 256 & 256 & 97 \\
\hline Imipenem & 16 & $\leq 0.25$ & $\leq 0.25$ & $\leq 0.25$ & 0 \\
\hline Metronidazole & 16 & $\leq 0.25-4$ & $\leq 0.25$ & 2 & 0 \\
\hline Penicillin G & 8 & $1-256$ & 32 & 256 & 87.5 \\
\hline Tetracycline & 8 & $\leq 0.25-32$ & 16 & 16 & 51.5 \\
\hline \multicolumn{6}{|l|}{ Children without diarrhea } \\
\hline Amoxicillin & 8 & $4-256$ & 256 & 256 & 96 \\
\hline Amoxcillin/Clavulanic acid & 8 & $0.5-256$ & 16 & 64 & 56 \\
\hline Ampicillin & 4 & $4-256$ & 128 & 256 & 98 \\
\hline Cefoxitin & 16 & $\leq 0.25-128$ & 16 & 32 & 22 \\
\hline Clindamycin & 8 & $\leq 0.25-256$ & 4 & 256 & 30 \\
\hline Chloramphenicol & 16 & $32-256$ & 128 & 128 & 100 \\
\hline Erythromycin & 8 & $16-256$ & 256 & 256 & 100 \\
\hline Imipenem & 16 & $\leq 0.25-2$ & $\leq 0.25$ & $\leq 0.25$ & 0 \\
\hline Metronidazole & 16 & $\leq 0.25-4$ & $\leq 0.25$ & $\leq 0.25$ & 0 \\
\hline Penicillin G & 8 & $8-256$ & 256 & 256 & 92 \\
\hline Tetracycline & 8 & $\leq 0.25-16$ & 16 & 16 & 54 \\
\hline
\end{tabular}

a: susceptibility for $B$. fragilis ATCC 43858: amoxicillin, $64 \mu \mathrm{g} / \mathrm{ml}$; amoxicillin/clavulanic acid, $2 \mu \mathrm{g} / \mathrm{ml}$; ampicillin, $16 \mu \mathrm{g} / \mathrm{ml}$; cefoxitin, $16 \mu \mathrm{g} / \mathrm{ml}$; clindamycin, $256 \mu \mathrm{g} / \mathrm{ml}$; chloramphenicol, $128 \mu \mathrm{g} / \mathrm{ml}$; erythromycin, $256 \mu \mathrm{g} / \mathrm{ml}$; imipenem, $\leq 0.25 \mu \mathrm{g} / \mathrm{ml}$; metronidazole, $\leq$ $0.25 \mu \mathrm{g} / \mathrm{ml}$; penicillin G, $16 \mu \mathrm{g} / \mathrm{ml}$; and tetracycline. For $B$. fragilis GAI 97124: amoxicillin, $256 \mu \mathrm{mg} / \mathrm{ml}$; amoxicillin/clavulanic acid, $16 \mu \mathrm{g} / \mathrm{ml}$; ampicillin, $256 \mu \mathrm{g} / \mathrm{ml}$; cefoxitin, $16 \mu \mathrm{g} / \mathrm{ml}$; clindamycin, $256 \mu \mathrm{g} / \mathrm{ml}$; chloramphenicol, $64 \mu \mathrm{g} / \mathrm{ml}$; erythromycin, $256 \mu \mathrm{g} / \mathrm{ml}$; imipenem, $\leq 0.25 \mu \mathrm{g} / \mathrm{ml}$; metronidazole, $\leq 0.25 \mu \mathrm{g} / \mathrm{ml}$; penicillin $\mathrm{G}, 256 \mu \mathrm{g} / \mathrm{ml}$; and tetracycline, $16 \mu \mathrm{g} / \mathrm{ml}$

TABLE II

Metal ions activity against 114 species of the Bacteroides fragilis group isolated from intestinal microbiota of children with (64) and without (50) diarrhea

\begin{tabular}{|c|c|c|c|c|}
\hline \multirow[b]{2}{*}{ Metals $a$} & \multicolumn{3}{|c|}{$\mathrm{MIC}(\mathrm{mg} / \mathrm{ml})$} & \multirow[b]{2}{*}{ Resistance (\%) } \\
\hline & Range & $50 \%$ & $90 \%$ & \\
\hline \multicolumn{5}{|c|}{ Children with diarrhea } \\
\hline $\mathrm{HgCl}_{2}$ & $\leq 0.25-8$ & 4 & 8 & 59 \\
\hline $\mathrm{AgNO}_{3}$ & $\leq 0.25-32$ & 16 & 32 & 70 \\
\hline $\mathrm{CuSO}_{4}^{3}$ & $\leq 0.25-256$ & 16 & 64 & 68.5 \\
\hline $3 \mathrm{CdSO}_{4} .8 \mathrm{H}_{2} \mathrm{O}$ & $\leq 0.25-128$ & 16 & 128 & 68.5 \\
\hline $\mathrm{PbCl}_{2}$ & $64-\geq 512$ & 512 & $\geq 512$ & 100 \\
\hline $\mathrm{NiSO}_{4} \cdot 6 \mathrm{H}_{2} \mathrm{O}$ & $128-\geq 512$ & 512 & $\geq 512$ & 100 \\
\hline \multicolumn{5}{|c|}{ Children without diarrhea } \\
\hline $\mathrm{HgCl}_{2}$ & $\leq 0.25-4$ & 4 & 4 & 80 \\
\hline $\mathrm{AgNO}_{3}$ & $\leq 0.25-32$ & 16 & 16 & 94 \\
\hline $\mathrm{CuSO}_{4}^{3}$ & $\leq 0.25-64$ & 32 & 64 & 86 \\
\hline $3 \mathrm{CdSO}_{4} \cdot 8 \mathrm{H}_{2} \mathrm{O}$ & $8-128$ & 16 & 32 & 100 \\
\hline $\mathrm{PbCl}_{2}$ & $128-\geq 512$ & $\geq 512$ & $\geq 512$ & 100 \\
\hline $\mathrm{NiSO}_{4} \cdot 6 \mathrm{H}_{2} \mathrm{O}$ & $64-\geq 512$ & 512 & 512 & 100 \\
\hline
\end{tabular}

$a$ : the breakpoint for all metals was $2 \mu \mathrm{g} / \mathrm{ml}$; susceptibility for B. fragilis (ATCC 43858): $\mathrm{HgCl}_{2}, 4 \mu \mathrm{g} / \mathrm{ml} ; \mathrm{AgNO}_{3} 8 \mu \mathrm{g} / \mathrm{ml}$; CuSO , $32 \mu \mathrm{g} / \mathrm{ml} ; 3 \mathrm{CdSO}_{4} .8 \mathrm{H}_{2} \mathrm{O}, 16 \mu \mathrm{g} / \mathrm{ml} ; \mathrm{PbCl}_{2}, \geq 512 \mu \mathrm{g} / \mathrm{ml} ;$ and $\mathrm{NiSO}_{4} \cdot 6 \mathrm{H}_{2} \mathrm{O}, \geq 512 \mu \mathrm{g} / \mathrm{ml}$. For B. fragilis $(\mathrm{GAI} 97124): \mathrm{HgCl}_{2} 4 \mu \mathrm{g} /$ $\mathrm{ml} ; \mathrm{AgNO}_{3}, 0.5 \mu \mathrm{g} / \mathrm{ml} ; \mathrm{CuSO}_{4}, 8 \mu \mathrm{g} / \mathrm{ml} ; 3 \mathrm{CdSO}_{4} .8 \mathrm{H}_{2} \mathrm{O}, \leq 0.25 \mu \mathrm{g} / \mathrm{ml} ; \mathrm{PbCl}_{2}, \geq 512 \mu \mathrm{g} / \mathrm{ml} ;$ and NiSO $4.6 \mathrm{H}_{2} \mathrm{O}, 256 \mu \mathrm{g} / \mathrm{ml}$ 
TABLE III

$\beta$-lactamase production of species of the Bacteroides fragilis group isolated from intestinal microbiota of children with (64) and without (50) diarrhea

\begin{tabular}{|c|c|c|c|c|c|c|c|c|c|}
\hline \multirow[b]{4}{*}{ Species $(\mathrm{Nr})$} & \multicolumn{4}{|c|}{ Children with diarrhea } & \multicolumn{5}{|c|}{ Children without diarrhea } \\
\hline & \multicolumn{4}{|c|}{$\beta$-lactamase producers } & \multirow[b]{3}{*}{ Species $(\mathrm{Nr})$} & \multicolumn{4}{|c|}{$\beta$-lactamase producers } \\
\hline & \multicolumn{2}{|c|}{$\mathrm{BM}$} & \multicolumn{2}{|c|}{ NM } & & \multicolumn{2}{|c|}{ B M } & \multicolumn{2}{|c|}{ NM } \\
\hline & $\mathrm{Nr}$ & $\%$ & $\mathrm{Nr}$ & $\%$ & & $\mathrm{Nr}$ & $\%$ & $\mathrm{Nr}$ & $\%$ \\
\hline B. fragilis (39) & 19 & 48.7 & 34 & 87.1 & B. fragilis (27) & 16 & 59.2 & 25 & 92.5 \\
\hline B. vulgatus (8) & 5 & 62.5 & 7 & 87.5 & B. distasonis (10) & 6 & 60 & 8 & 80 \\
\hline B. distasonis (6) & 4 & 66.6 & 6 & 100 & B. vulgatus (6) & 5 & 83.3 & 6 & 100 \\
\hline B. uniformis (6) & 3 & 50 & 6 & 100 & B. eggerthii (2) & 1 & 50 & 2 & 100 \\
\hline \multirow[t]{3}{*}{ B. ovatus (5) } & 1 & 20 & 5 & 100 & B. ovatus (2) & 1 & 50 & 2 & 100 \\
\hline & & & & & B. thetaiotaomicron (2) & 0 & 0 & 1 & 50 \\
\hline & & & & & B. uniformis (1) & 1 & 100 & 1 & 100 \\
\hline Total (64) & 32 & 50 & 58 & 90.6 & Total (50) & 30 & 60 & 45 & 90 \\
\hline
\end{tabular}

BM: biological method; NM: nitrocefin method; $\beta$-lactamase-positive $B$. fragilis ATCC 43858 and GAI 97127 were used in both methods.

\section{DISCUSSION}

Species of the $B$. fragilis group are the anaerobic bacteria most commonly associated with a wide variety of endogenous clinical infections, especially $B$. fragilis species. These organisms represent $75 \%$ of post-operative intra-abdominal infections and approximately $100 \%$ in cases of appendicitis (Aldridge et al. 2001). In this study, the survey of antibiotics and metals susceptibility as well as the resistance profile of species of the $B$. fragilis isolated from children intestinal microbiota was performed.

Clindamycin resistance among clinical isolates of Bacteroides has increased in several countries. However, in Europe and in the US, the clindamycin (Aldridge et al. 2001, Wexler et al. 2001) resistance is below $22 \%$ compared with 35\% in Brazil, Japan, and Spain (Almeida \& Uzeda, 1987, Baquero \& Reig, 1992, Bandoh et al. 1993). Similar resistance rate is mentioned to cephalosporin in Canada and France (Bourgault et al. 1992, Dubreuil et al. 1992).

In this study, B. fragilis strains isolated from children without diarrhea showed a similar resistance to several antimicrobials with that ones isolated from diarrhea (Table I). All the strains from both groups were $100 \%$ resistant to lead and nickel. The high resistance observed to antibiotics and metals in Bacteroides species can be explained because the self-medication is common in countries such as Brazil, where policies about medication are not strict. Moreover, all tested organisms were susceptible to imipenem and metronidazole, according to literature (Mol et al. 1991, Aldridge et al. 2001, Wexler et al. 2001). On the other hand, antimicrobial resistance has been associated with plasmids, except for metronidazole (Breuil et al. 1989) and imipenem (Bandoh et al. 1992), and conjugative transposon such as $\mathrm{Tn} 4555$ have been recently described to be associated with cefoxitin resistance, encoding the cfxA gene (Tribble et al. 1999).

During the last 20 years, species of the $B$. fragilis group have shown an increase of the resistance to most of the antimicrobial agents traditionally used for treating anaerobic infections (Sanders \& Aldridge 1992).
Clindamycin and cefoxitin resistance have been reported since 1980 and recently, although rare, resistances to imipenem and metronidazole have also been described (Bourgault et al. 1992, O’Donogue et al. 1992). In this study, the resistance rates to clindamycin were $34.5 \%$ and $30 \%$ for strains from children with and without diarrhea, respectively. Clindamycin resistance frequently has been shown to be conferred by a macrolide-lincosamidestreptogramin B resistance (MLS). Therefore, the clinical use of clindamycin or erythromycin may increase the frequency of clindamycin-resistant strains among Bacteroides species (Macrina \& Smith 1993).

Interestingly, resistance rates of $23.5 \%$ and $22 \%$ to cefoxitin for strains isolated from children with and without diarrhea, respectively, were observed. This should be attributed to the wide and indiscriminate use of macrolides, lincosamides and $\beta$-lactams in Brazil (Carvalho et al. 1997). Resistance rates ranging from 16 to $22 \%$ to cefoxitin have also been documented in other studies (Dubreil et al. 1984, Garcia-Rodriguez \& Garcia-Sánchez 1990). In other Brazilian study, Almeida and Uzeda (1987) reported high resistance levels to clindamycin (37\%) and cefoxitin (21\%) among $B$. fragilis group strains isolated from the human intestinal microbiota. Moreover, Avelar et al. (2001) found high levels of resistance of the $B$. fragilis group isolated from children and adults to clindamycin (72.7\% and 58.3\%), and to cefoxitin $(8.3 \%$ and $13.5 \%)$, respectively. Moreover, tetracycline resistance rates were $51.5 \%$ and $54 \%$ for bacteria isolated from children with and without diarrhea, respectively, according to Sanders and Aldridge (1992) and Carvalho et al. (1997).

By using biological and nitrocefin methods, the $\beta$ lactamase production was respectively observed in 32 $(50 \%)$ and $58(90.6 \%)$ isolates from children with diarrhea, and in $30(60 \%)$ and $45(90 \%)$ isolates from healthy children. Moreover, all the $\beta$-lactamase-positive isolates observed by using a biological method also were positive to nitrocefin method. These results suggest that the last method is more sensible than the biological one to detect the $\beta$-lactamase activity. However, it is important to note 
that biological method was tested only with penicillinresistant isolates. On the other hand, the nitrocefin method is recommended to detect the cephalosporinase and the penicillinase activity. Cáceres et al. (2000) and Aldridge et al. (2001) verified the $\beta$-lactamase production in $97.5 \%$ and in $77 \%$ of the B. fragilis tested, respectively. Most of the enzymes are chromosomally mediated cephalosporinases with activities against many narrowand-broad-spectrum penicillins and cephalosporins (Bush 1988, Rasmussen et al. 1997).

It is mentioned that the bacteria with antimicrobial resistance mechanisms are able to grow and to multiply in gradual higher concentrations of antibiotics and heavy metals. Moreover, it is also suggested that both genetic and physiological bacterial factors could selectively suppress the susceptibility to the antibiotic killing action (Tuomanen et al. 1986). Since a bacterial population consists of different subpopulation of cells there is much to be elucidated on these phenomena among bacteria of the B. fragilis group (Avila-Campos et al. 1991).

In their usual habitats, these indigenous microorganisms are constantly exposed to various antimicrobial agents, including heavy metals. The literature on biochemical-physiological mechanisms of susceptibility and on the resistance of microorganisms to some chemical agents, such as heavy metals, is not convincing, but it is suggested that the phenomena could be either chromosome- or plasmid-mediated (Rudrick et al. 1985).

Gram-negative bacteria such as Escherichia coli, Salmonella typhimurium, and Pseudomonas sp. carrying transferable plasmids have showed resistance to mercuric ions (Summers \& Silver 1978). Moreover, studies have shown that Bacteroides spp. harboring plasmid show resistance to several antimicrobial drugs, but not to heavy metals (Tinnel \& Macrina 1976). According to Riley and Mee (1982), it is possible that the heavy metals resistance in this microbial group would be intrinsic, rather than plasmid borne.

In this study, a multiple resistance to antibiotics and/ or metals was observed in all species of the $B$. fragilis group isolated from children with and without diarrhea. A resistance rate of $100 \%$ was observed to lead and nickel in both analyzed children groups, and to cadmium only in strains isolated from children without diarrhea. These data can be the results of a continue contamination with these metallic ions by agriculture or ground way of humans and animals, mainly in some Brazilian countries such as São Paulo City.

On the other hand, the presence of plasmid in these tested strains was associated to antibiotic-resistance but not to metals (data not shown). This result suggests that the metal-resistance in B. fragilis is chromosomally mediated in accordance with Riley and Mee (1982). Resistance rates of $\mathrm{HgCl}_{2}, \mathrm{AgNO}_{3}$ and $\mathrm{CuSO}_{4}$ were from 68.5 to $94 \%$, probably partly due to the wide use of these metallic ions in medical centers. Therefore, a political program of using metals and antibiotics is urgent in order to save those therapeutic treatments. Finally, considering the endogenous origin of these bacteria and the conjugal transfer properties among intestinal bacteria, these results are worrisome, and they reaffirm the need to increase the an- tibiotics and metals resistance surveillance of this microbial group in Brazil.

\section{ACKNOWLEDGEMENTS}

To Mrs Zulmira Alves de Souza for her technical support.

\section{REFERENCES}

Aldridge KE, Ashcraft D, Cambre K, Pierson CL, Jenkins SG, Rosenblatt JE 2001. Multicenter survey of the changing in vitro antimicrobial susceptibility of clinical isolates of Bacteroides fragilis group, Prevotella, Fusobacterium, Porphyromonas, and Peptostreptococcus species. Antimicrob Agents Chemother 45: 1238-1243.

Almeida AECC, Uzeda M 1987. Susceptibility to five antimicrobial agents of strains of the Bacteroides fragilis group isolated in Brazil. Antimicrob Agents Chemother 31: 617618.

Avelar KES, Vieira JMBD, Antunes LCM, Lobo LA, Antunes ENF, Domingues RMCP, Ferreira MCS 2001. Antimicrobial resistance of strains of Bacteroides fragilis group isolated from the intestinal tract of children and adults in Brazil. Int J Ant Agents 18: 129-134.

Avila-Campos MJ, Carvalho MAR, Damasceno CAV, ChartoneSouza E, Cisalpino EO 1991. Population stability in species of the Bacteroides fragilis group, under mercuric chloride action. Rev Microbiol 22: 93-96.

Bandoh K, Watanabe K, Muto Y, Tanaka Y, Kato N, Ueno K 1992. Conjugal transfer of imipenem in Bacteroides fragilis. J Antibiot 45: 542-547.

Bandoh K, Ueno K, Watanabe K, Kato N 1993. Susceptibility patterns and resistance to imipenem in the Bacteroides fragilis group species in Japan. Clin Infect Dis 16: s382386.

Baquero F, Reig M 1992. Resistance of anaerobic bacteria to antimicrobial agents in Spain. Eur J Clin Microbiol Infect Dis 11: 292-304.

Bartlett JG, Marien GJR, Dezfulian M, Joiner M 1983. Relative efficacy of $\beta$-lactam antimicrobial agents in two animal models of infections involving Bacteroides fragilis. Rev Infect Dis 5: 338-344.

Bezirtzoglou E 1997. The intestinal microflora during the first weeks of life. Anaerobe 3: 173-177.

Bourgault AM, Lamothe F, Hoban DJ, Dalton MT, Kisbey PC, Harding G 1992. Survey of Bacteroides fragilis group susceptibility patterns in Canada. Antimicrob Agents Chemother 36: 343-347.

Breuil J, Dublanchet A, Truffaut N, Sebald M 1989. Transferable 5-nitroimidazole resistance in the Bacteroides fragilis group. Plasmid 21: 151-154.

Bush K 1988. $\beta$-lactamase inhibitors from laboratory clinic. Clin Microbiol Rev 1: 109-123.

Cáceres M, Zhang G, Weintraub A, Nord CE 2000. Prevalence and antimicrobial susceptibility of enterotoxigenic Bacteroides fragilis in children with diarrhea in Nicaragua. Anaerobe 6: 143-148.

Carvalho CBM, Moreira JLB, Ferreira MCS 1997. Survey of Bacteroides fragilis group susceptibility patterns in Brazil. Int J Antimicrob Agents 8: 115-120.

Dubreuil L, Breuil J, Dublanchet A, Sedallian A 1992. Survey of the susceptibility patterns of Bacteroides fragilis group strains in France from 1977 to 1992. Eur J Clin Microbiol Infect Dis 11: 1094-1099.

Dubreuil L, Devos J, Neut C, Romond C 1984. Susceptibility of anaerobic bacteria from several French hospitals to three major antibiotics. Antimicrob Agents Chemother 25: 764766.

Duerden BI 1994. Virulence factors in anaerobes. Clin Infect 
Dis 18: 253-259.

Garcia-Rodriguez JE, Garcia-Sánchez JE 1990. Evolution of antimicrobial susceptibility in isolates of the Bacteroides fragilis in Spain. Rev Infect Dis 12: 142-151.

Holdeman LV, Cato EP, Moore WE 1977. Anaerobic Laboratory Manual, 4th ed., Virginia Polytechnic Institute, Blackburg, VA.

Kunin CM 1993. Resistance to antimicrobial drugs: a worldwide calamity. Ann Int Med 118: 557-561.

Macrina FL, Smith CJ 1992. Gene transmission, MLS, and tetracycline resistance in Bacteroides. In M Sebald, Genetics and Molecular Biology of Anaerobic Bacteria, SpringerVerlag, New York, p. 474-489.

Mol CG, Avila-Campos MJ, Carvalho MAR, Damasceno CAV, Cisalpino EO 1991. In vitro susceptibility to four antimicrobial agents of strains of the Bacteroides fragilis group isolated in Brazil. Rev Microbiol 22: 191-193.

Nakahara H, Ishikawa T, Sarai Y, Kondo I, Mitsuhashi S 1977. Frequency of heavy-metals resistance in bacteria from patient in Japan. Nature 266: 165-167.

NCCLS-National Committee for Clinical Laboratory Standards 1997. Methods for Dilution Antimicrobial Susceptibility Testing of Anaerobic Bacteria, 4th ed., Approved Standard M11-A4. NCCLS, Villanova, PA, US.

O’Donogue MAT, Potter J, Allen MD 1992. Metronidazoleresistant Bacteroides fragilis wound infection. J Infect 25: 211-214.

Paula MO, Gaetti-Jardim E, Avila-Campos MJ 2003. Plasmid profile in oral Fusobacterium nucleatum from humans and Cebus apella monkeys. Rev Inst Med Trop São Paulo 45: 59.

Rasmussen BA, Bush K, Tally FP 1997. Antimicrobial resistance in anaerobes. Clin Infect Dis 24: 110-120.
Riley TV, Mee BJ 1982. Susceptibility of Bacteroides spp. to heavy metals. Antimicrob Agents Chemother 22: 889-892.

Rudrik JT, Bawdon RE, Guss SP 1985. Determination of mercury and organ mercurial resistance in obligate anaerobic bacteria. Can J Microbiol 31: 276-281.

Salyers AA 1984. Bacteroides of the human lower intestinal tract. Ann Rev Microbiol 38: 293-313.

Sanders CV, Aldridge KE 1992. Current antimicrobial therapy of anaerobic infections. Eur J Clin Microbiol Infect Dis 11: 999-1011.

Sebald M 1994. Genetic basis for antibiotic resistance in anaerobes. Clin Infect Dis 18: 297-304.

Summers AO, Silver S 1978. Microbial transformation of metals. Ann Rev Microbiol 32: 637-672.

Tally FP, Sydndman DR, Gorbach SL, Malamy MII 1979. Plasmid-mediated transferable resistance to clindamycin and erythromycin in Bacteroides fragilis. J Infect Dis 139: 8388.

Tinnel WH, Macrina FL 1976. Extra chromosomal elements in a variety of strains representing the Bacteroides fragilis group of organisms. Infect Immun 14: 955-964.

Tribble GD, Parker AC, Smith CJ 1999. Genetic structure and transcriptional analysis of a mobilizable antibiotic resistance transposon from Bacteroides. Plasmid 42: 1-12.

Tuomanen E, Durack DT, Tomasz A 1986. Antibiotic tolerance among clinical isolates of bacteria. Antimicrob Agents Chemother 30: 521-527.

Welch RA, Jones KR, Macrina FL 1979. Tansferable lincosamide-macrolide resistance in Bacteroides. Plasmid 2: $261-268$

Wexler HM, Molitoris D, Finegold SM 2001. In vitro activity of gatifloxacin against 238 strains of anaerobic bacteria. Anaerobe 7: 285-289. 